\title{
Nitric Oxide Alleviated Arsenic Toxicity by Modulation of Antioxidants and Thiol Metabolism in Rice (Oryza sativa L.)
}

\author{
Amit P. Singh ${ }^{1}$, Garima Dixit' ${ }^{1}$, Amit Kumar' ${ }^{1}$, Seema Mishra ${ }^{1}$, Pradyumna K. Singh' \\ Sanjay Dwivedi', Prabodh K. Trivedi', Debasis Chakrabarty', Shekhar Mallick', \\ Vivek Pandey ${ }^{1}$, Om P. Dhankher ${ }^{2}$ and Rudra D. Tripathi' ${ }^{*}$ \\ ${ }^{1}$ C.S.I.R.-National Botanical Research Institute, Lucknow, India, ${ }^{2}$ Stockbridge School of Agriculture, University of \\ Massachusetts Amherst, Amherst, MA, USA
}

\section{OPEN ACCESS}

Edited by:

Shabir Hussain Wani,

Sher-e-Kashmir University

of Agricultural Sciences

and Technology of Kashmir, India

Reviewed by:

Sudhakar Srivastava

Banaras Hindu University, India

Meetu Gupta,

Jamia Millia Islamia, India

*Correspondence:

Rudra D. Tripathi

tripathird@gmail.com;

tripathi_rd@rediffmail.com

Specialty section:

This article was submitted to Crop Science and Horticulture,

a section of the journal

Frontiers in Plant Science

Received: 15 October 2015 Accepted: 28 December 2015

Published: 12 January 2016

Citation:

Singh AP, Dixit G, Kumar A, Mishra S,

Singh PK, Dwivedi S, Trivedi PK, Chakrabarty D, Mallick S, Pandey V, Dhankher OP and Tripathi RD (2016) Nitric Oxide Alleviated Arsenic Toxicity by Modulation of Antioxidants and Thiol Metabolism in Rice (Oryza sativa L.). Front. Plant Sci. 6:1272. doi: 10.3389/fpls.2015.01272
Nitric oxide (NO) is a gaseous signaling molecule and has a profound impact on plant growth and development. It is reported to serve as pro oxidant as well as antioxidant in plant system. In the present study, we evaluated the protective role of $\mathrm{NO}$ against arsenate $\left(A s^{\vee}\right)$ toxicity in rice plants. $A s^{\vee}$ exposure has hampered the plant growth, reduced the chlorophyll content, and enhanced the oxidative stress, while the exogenous NO supplementation has reverted these symptoms. NO supplementation has reduced the arsenic (As) accumulation in root as well as shoot. NO supplementation to $\mathrm{As}^{\mathrm{V}}$ exposed plants has reduced the gene expression level of OsLsi1 and OsLsi2. As ${ }^{\mathrm{V}}$ stress significantly impacted thiol metabolism, it reduced GSH content and GSH/GSSG ratio, and enhanced the level of PCs. NO supplementation maintained the GSH/GSSG ratio and reduced the level of PCs. NO supplementation reverted As ${ }^{V}$ induced iron deficiency in shoot and had significant impact of gene expression level of various iron transporters (OsYSL2, OsFRDL1, OsIRT1, and OsIRO2). Conclusively, exogenous application of $\mathrm{NO}$ could be advantageous against $\mathrm{As}^{\mathrm{V}}$ toxicity and could confer the tolerance to $\mathrm{As}^{\mathrm{V}}$ stress in rice.

Keywords: arsenate, arsenic transporter, iron transporter, nitric oxide, non-protein thiol, rice

\section{INTRODUCTION}

Arsenic (As) is ubiquitous element in the earth crust and present in almost all type of soils. As and its compounds are classified as Group 1 carcinogens by International Agency for Research on Cancer. High doses of As can cause death, but chronic lower level exposures result in serious health problems such as skin lesions and cancer (Kumar et al., 2015). As contamination in drinking water is main source of As exposure for humans and when this As contaminated water is used for irrigation of crops and fodder it becomes part of food chain (Finnegan and Chen, 2012). Bangladesh and West Bengal (India) are extremely high As contaminated regions where As concentration in water has been reported up to $3200 \mu \mathrm{gL}^{-1}$ against the safe limit of $10 \mu \mathrm{gL}^{-1}$ recommended by WHO (McCarty et al., 2011). As exists as inorganic as well as organic form in environment. Arsenate $\left(\mathrm{As}^{\mathrm{V}}\right)$ and arsenite $\left(\mathrm{As}{ }^{\mathrm{III}}\right)$ are two principal forms of inorganic As. As ${ }^{\mathrm{V}}$ form predominates in aerobic soil while under reduced condition $\mathrm{As}^{\mathrm{III}}$ form predominates. Rice is 
grown under flooded conditions where $\mathrm{As}{ }^{\mathrm{III}}$ form dominates. Further, most of the As taken up by the plants is also reduced and stored as As ${ }^{\mathrm{III}}$. The two inorganic forms of As; $\mathrm{As}^{\mathrm{III}}$ and $\mathrm{As} \mathrm{V}^{\mathrm{V}}$ gets entry in to plant system through aquaporins and phosphate transporters, respectively (Tripathi et al., 2007; Dixit et al., 2015a). Two well known aquaporin transporters of $\mathrm{As}^{\mathrm{III}}$ in rice are OsLsi1, that is responsible for uptake of As ${ }^{\text {II }}$ in to root cells from external medium and OsLsi2 is a efflux transporter and responsible for $\mathrm{As}^{\mathrm{III}}$ accumulation in shoot and grain (Ma et al., 2008).

Arsenic is non-essential toxic element for plant growth and development. Rice is an efficient accumulator of As and unfortunately, major output of rice comes from these As contaminated regions thus elevated As accumulation in rice may become disaster (Kumar et al., 2015). As also affects the amino acid profile and elemental content of grain that reduces the nutritional value of rice (Kumar et al., 2014a). Numerous physiological processes in plant system are susceptible for As toxicity (Srivastava et al., 2015). As exposure induces reactive oxygen species (ROS) synthesis which leads to cellular membrane damage (Kumar et al., 2013, 2014b). To cope with enhanced level of oxidative stress plants are equipped with antioxidant system that gets activated under As stress conditions (Gupta and Ahmad, 2014; Singh et al., 2015). As induces the synthesis of phytochelatins (PCs) that bind to As ${ }^{\mathrm{III}}$ and sequester it into vacuole and reduces the free As in cytoplasm (Dixit et al., 2015b).

Nitric oxide (NO) is a gaseous free radical molecule and serves as an effective signaling molecule in plant system. NO plays a crucial role in immune response against pathogen attack in plants (Bellin et al., 2013). Exogenously supplied NO has been demonstrated to provide a protection against heavy metals such as copper (Yu et al., 2005), aluminum (Sun et al., 2014), manganese (Srivastava and Dubey, 2012), As (Singh et al., 2009), and cadmium (Singh et al., 2008). NO can neutralize heavy metal induce ROS in two ways, first being a free radical it can directly react with ROS and neutralize them (Laspina et al., 2005) and second being a signaling molecule, it may stimulate antioxidant system to abate oxidative stress (Lamattina et al., 2003; Laspina et al., 2005). NO brings the post translational modification of proteins by nitrosylating their cysteine residue. Ascorbate peroxidase (APX), catalase (CAT), and superoxide dismutase (SOD) are good candidates for NO regulated antioxidants in plants (Groß et al., 2013). NO is associated with iron (Fe) homeostatic and mediates the Fe dependent ferritin expression in Arabidopsis (Murgia et al., 2002). Under Fe deficient conditions $\mathrm{NO}$ is rapidly produced in roots and activates $\mathrm{Fe}$ starvation pathways (Graziano and Lamattina, 2007). Exogenous NO also have profound impact on genes involved in Fe uptake (Koen et al., 2012).

Plants follow two different mechanisms for iron (Fe) acquisition; Strategy I in non-graminaceous plants and Strategy II in graminaceous plants (Römheld and Marschner, 1986). In Strategy I, ferric chelates $\left(\mathrm{Fe}^{+3}\right.$ chelate) are reduced in to ferrous $\left(\mathrm{Fe}^{+2}\right)$ ions at the root surface and so generated $\mathrm{Fe}^{+2}$ ions are absorbed across the plasma membrane (Kobayashi and Nishizawa, 2012). Rice follows Strategy II for Fe uptake, where plant roots secrete mugineic acid (MA) that form $\mathrm{Fe}^{+3}$-MA complex which is taken up by root cells by YSL transporters (Kobayashi and Nishizawa, 2012). Various transporters such as OsFRDL1, OsYSL2, and OsNRAMP5 are involved for Fe transport in rice through Strategy II. $\mathrm{Fe}^{+2}$ is abundant form of $\mathrm{Fe}$ in submerged and anaerobic conditions thus to uptake $\mathrm{Fe}^{+2}$ rice plant has a unique transporter OsIRT1, which facilitates this crop to absorb $\mathrm{Fe}^{+2}$ directly, however, it is the unique feature of Strategy I plants (Kobayashi and Nishizawa, 2012). OsIRO2 is key regulator of various Fe transporters (Ogo et al., 2007). OsFRDL1 is expressed in rice root pericycle and encodes citrate effluxer, that is required for efficient Fe translocation (Yokosho et al., 2009) and OsYSL2 is responsible for long distance transport of chelated $\mathrm{Fe}^{+3}$ to sink tissues (Ishimaru et al., 2010).

The present study aims to investigate the role of exogenously supplied NO (SNP as NO donor) for alleviation of $\mathrm{As}^{\mathrm{V}}$ toxicity in hydroponically grown rice. SNP releases $\mathrm{NO}$ in the form of nitrosonium cation $\left(\mathrm{NO}^{+}\right)$on its reaction with thiolic legends (RSH). An electron-transfer process is key step, which leads to the formation of the reduced SNP radical and the corresponding $S$-nitrosothiol, that is storage form of NO (Grossi and D'Angelo, 2005). NO release from SNP also largely depends upon light intensity (Lum et al., 2005). The study elucidates impact of exogenously supplied NO on antioxidants, non-protein thiol (NPT) metabolism, accumulation of As and Fe and expression of various $\mathrm{Fe}$ and $\mathrm{As}{ }^{\mathrm{III}}$ transporters against moderate $(25 \mu \mathrm{M})$ and high $(50 \mu \mathrm{M})$ doses of $A s^{\mathrm{V}}$.

\section{METHODS AND MATERIALS}

\section{Growth Conditions and Experimental Design}

Seeds of Oryza sativa cv. Jaya collected from Masina Research Centre, Pvt. Ltd., Bihar (India), were surface sterilized using $10 \% \mathrm{H}_{2} \mathrm{O}_{2}$ for $30 \mathrm{~s}$ and washed with Milli-Q water. Seeds were germinated on moist pre-sterilized blotting sheets layered on a tray in seed germinator for 4 days at $25^{\circ} \mathrm{C}$ and relative humidity was $65 \%$. After 7 days, uniform size seedlings were selected and placed in $150 \mathrm{ml}$ beakers, covered with black sheet, containing $100 \mathrm{ml}$ of $100 \%$ Hewitt nutrient medium, prepared in Milli-Q water ( $\mathrm{pH}$ 6.8-7.0) and grown for another 10 days under light intensity $210 \mu \mathrm{M} \mathrm{cm}^{-2} \mathrm{~s}^{-1}$ (16/8 h; day/night) before treatment. After 10 days of growth in nutrient medium, treatments were provided as $\mathrm{As}^{\mathrm{V}}(25$ and $50 \mu \mathrm{M})$ using the salt $\mathrm{Na}_{2} \mathrm{HAsO}_{4}$ and NO $(100 \mu \mathrm{M})$ using salt sodium nitroprusside (SNP, a NO donor) for 7 days. Plants treated by 25 or $50 \mu \mathrm{M}$ As ${ }^{\mathrm{V}}$ or $100 \mu \mathrm{M}$ SNP are abbreviated as $\mathrm{As}^{\mathrm{V}} 25$, $\mathrm{As}^{\mathrm{V}} 50$, and $\mathrm{NO}$, respectively. Plants treated with $\mathrm{As}^{\mathrm{V}} 25$ or $\mathrm{As}^{\mathrm{V}} 50$ supplemented with $\mathrm{NO}$ are abbreviated as $\mathrm{NO}+\mathrm{As}^{\mathrm{V}} 25$ and $\mathrm{NO}+\mathrm{As}^{\mathrm{V}} 50$. Plants grown only in Hewitt solution served as control. In the present study, SNP is used as efficient $\mathrm{NO}$ donor because it give rise to a persistent pattern of NO generation than other NO donors (Mur et al., 2013).

\section{Estimation of Photosynthetic Pigments}

For chlorophyll estimation, $100 \mathrm{mg}$ fresh leaves were crushed in $5 \mathrm{ml}$ of $80 \%$ chilled acetone and homogenate was centrifuged at $10,000 \times g$ for $10 \mathrm{~min}$. Chlorophyll and carotenoid content in 
supernatant was estimated as described by the method of Arnon (1949) and Duxbury and Yentsch (1956), respectively.

\section{Estimation of Lipid Peroxidation (MDA) and Hydrogen Peroxide}

For MDA and $\mathrm{H}_{2} \mathrm{O}_{2}$ estimation, $300 \mathrm{mg}$ fresh leaves or roots were crushed in $3 \mathrm{ml}$ of $0.2 \%$ trichloroacetic acid and homogenate was centrifuged at $10,000 \times g$ for $10 \mathrm{~min}$. and supernatant was collected for further estimation. MDA and $\mathrm{H}_{2} \mathrm{O}_{2}$ contents were estimated as described by Heath and Packer (1968) and Velikova et al. (2000), respectively.

\section{Determination of Antioxidant Enzymes and Nitrate Reductase Activities and Nitrite Level}

For analysis of enzyme activities, $300 \mathrm{mg}$ of fresh leaves or roots were ground in liquid $\mathrm{N}_{2}$, and extracted with $3 \mathrm{ml}$ of ice cold $100 \mathrm{mM}$ potassium phosphate buffer ( $\mathrm{pH} 7.8$ ) having 1\% (w/v) polyvinylpyrrolidone (PVP). The homogenate was centrifuged at $8000 \times g$ at $4^{\circ} \mathrm{C}$ for $15 \mathrm{~min}$ and supernatant was used for enzyme assays. The activity of SOD was measured by the method of Beauchamp and Fridovich (1971), APX by the method of Nakano and Asada (1981), GPX by the method of Kato and Shimizu (1987), and CAT by the method of Scandalios et al. (1983). The activity of nitrate reductase (NR) and the level of nitrite were determined by the method of Hageman and Reed (1980).

\section{Estimation of Non-protein Thiol Metabolites and Related Enzymes}

The level of GSH and GSSG was measured by following the method of Hissin and Hilf (1976). NPT content was measured by following the method of Ellman (1959). The concentration of PCs was calculated as PCs $=$ NPT $-($ GSH + GSSG; Duan et al., 2011).

Assay of cysteine synthase (CS) and $\gamma$-glutamylcysteine synthetase $(\gamma$-ECS) activities, was performed following the method of Seelig and Meister (1985) and Saito et al. (1994), respectively. The GR activity was assayed by following Smith et al. (1988). Glutathione-S-transferase (GST; EC 2.5.1.18) activity was assayed following Habig and Jakoby (1981). Estimation of Cysteine was performed using acid ninhydrin reagent by the method of Gaitonde (1967).

\section{Nitric Oxide and Reactive Oxygen Species Imaging}

For NO detection roots were incubated for $1 \mathrm{~h}$ at $25^{\circ} \mathrm{C}$, in darkness, with $10 \mathrm{mM}$ DAF-2DA (Calbiochem; excitation at $495 \mathrm{~nm}$, emission at $515 \mathrm{~nm})$ prepared in $10 \mathrm{mM}$ Tris- $\mathrm{HCl}(\mathrm{pH}$ 7.4), as described by Sandalio et al. (2008).

For ROS detection roots were incubated with $25 \mathrm{mM} \mathrm{H}_{2}$ DCFDA (Calbiochem; excitation at $485 \mathrm{~nm}$, emission at $530 \mathrm{~nm}$ ) for $1 \mathrm{~h}$ in darkness at $25^{\circ} \mathrm{C}$ as described by Rodríguez-Serrano et al. (2006). Then roots were washed three times for $10 \mathrm{~min}$ each with same buffer and fluorescence was visualized by confocal microscope, Zeiss LSM510 Meta.

\section{Elemental Analysis}

Element analysis was carried out by method of Mallick et al. (2013). Briefly, plant tissues root $(300 \mathrm{mg})$ and shoot $(500 \mathrm{mg})$ were oven dried at $70^{\circ} \mathrm{C}$ and digested in $\mathrm{HNO}_{3}: \mathrm{HCl}(3: 1)$. Digested samples were filtered through Whatman filter paper 42 and volume was made to $10 \mathrm{ml}$ by Milli-Q water. As and $\mathrm{Fe}$ were estimated by using AAS (GBC Avanta S, USA) fitted with a hydride generator (MDS2000) using $\mathrm{NaH}_{2} \mathrm{BO}_{4}+\mathrm{NaOH}(3 \mathrm{M})$ and $\mathrm{HCl}(3 \mathrm{M})$. The values were presented in $\mu$ g per gram dry weight $\left(\mu \mathrm{gg}^{-1} \mathrm{dw}\right)$.

\section{Gene Expression Analysis Using Quantitative RT-PCR}

Approximately $5 \mu \mathrm{g}$, RNase free DNase-treated, total RNA isolated from roots of rice plants was reverse-transcribed using SuperScriptII (Fermentas, USA), following the manufacturer's recommendation. The synthesized cDNA was diluted 1:5 in DEPC water and subjected to quantitative RT-PCR (qRTPCR) analysis. The qRT-PCR was performed using an ABI 7500 instrument (ABI Biosystems, USA) using primers listed in Supplementary Table S1. Each qPCR reaction mixture contained $5 \mu$ l of SYBR Green Supermix (ABI Biosystems, USA), $1 \mu \mathrm{l}$ of the diluted cDNA reaction mixture (corresponding to $5 \mathrm{ng}$ of starting amount of RNA) and $10 \mathrm{pM}$ of each primer in a total reaction volume of $10 \mu \mathrm{l}$. The qPCR reactions were performed under following conditions: $10 \mathrm{~min}$ at $95^{\circ} \mathrm{C}$ and 40 cycles of the one step thermal cycling of $3 \mathrm{~s}$ at $95^{\circ} \mathrm{C}$ and $30 \mathrm{~s}$ at $60^{\circ} \mathrm{C}$ in a 96 -well reaction plate. Actin gene was used as an internal control to estimate the relative transcript levels of the target gene. Specificity of amplicons generated in $\mathrm{qPCR}$ reactions was verified by melt curve analysis. Each $\mathrm{qPCR}$ reaction was performed in triplicate (technical replicates) for each biological replicate (three for each treatment). Relative gene expression was calculated using ${ }^{\Delta \Delta} \mathrm{CT}$ method of Livak and Schmittgen (2001).

\section{Statistical Analysis and Analytical Quality Control}

The whole experiment was set up in the randomized block design. The data were subjected to Duncan's Multiple Range Test (DMRT) for the analysis of significant difference between the treatments. Analytical data quality of the elements was ensured through repeated analysis $(n=6)$ of Standard Reference Material. Standard Certified reference material (CRM 028-050), procured from Resource Technology Corporation, USA (Lot no. IH 028), was used to check accuracy of the AAS. The blanks were run all the time to eliminate the background noise.

\section{RESULTS}

\section{Morphology}

Arsenate exposure hampered the plant growth and showed various symptoms of toxicity, such as chlorosis, growth inhibition, and necrosis (data not shown). In $\mathrm{As}^{\mathrm{V}}$ exposed plants, 
root hairs growth was hampered while, NO supplementation to $\mathrm{As}^{\mathrm{V}}$ exposed plants, reverted the root hairs growth and it was comparable to that of control plants (Supplementary Figure S1). A dose dependent significant decrease was observed in root, shoot length and biomass in $\mathrm{As}^{\mathrm{V}}$ exposed plants. $\mathrm{As}^{\mathrm{V}}$ exposed plants supplemented with NO showed better growth than $\mathrm{As}^{\mathrm{V}}$ alone stressed plants. Root, shoot length, and biomass were comparable with that of control in $\mathrm{As}^{\mathrm{V}}+\mathrm{NO}$ treatments. As ${ }^{\mathrm{V}}$ stress has reduced the total chlorophyll content 22 and $35 \%$ in $\mathrm{As}^{\mathrm{V}} 25$ and $\mathrm{As}^{\mathrm{V}} 50$ treated plants, respectively. NO supplementation to $\mathrm{As}^{\mathrm{V}}$ stressed plants overcame the $\mathrm{As}^{\mathrm{V}}$ induced chlorophyll decay and total chlorophyll content was comparable to that of control. As $\mathrm{V}$ and NO both had no significant impact on carotenoid content (Table 1).

\section{Endogenous Nitric Oxide}

Endogenous level of $\mathrm{NO}$ in root was estimated by $\mathrm{NO}$ mediated fluorescence. Exogenous application of NO enhanced the fluorescence than control root. In $\mathrm{As}^{\mathrm{V}}$ exposed plants NO dependent fluorescence was reduced than control while, $\mathrm{NO}$ supplementation to $\mathrm{As}^{\mathrm{V}}$ stressed plants has enhanced the fluorescence than alone $\mathrm{As}^{\mathrm{V}}$ stressed root (Figures 1A,B).

\section{Oxidative Stress}

Endogenous accumulation of ROS in root was carried out by $\mathrm{H}_{2}$ DCF-DA staining. NO treatment did not altered ROS dependent fluorescence significantly while, $\mathrm{As}^{\mathrm{V}}$ exposure has enhanced drastically. NO supplementation to $\mathrm{As}^{\mathrm{V}}$ exposed plants reduced the ROS dependent fluorescence than $\mathrm{As}^{\mathrm{V}}$ exposed roots (Supplementary Figures S2A,B).

Arsenate stress enhanced $\mathrm{H}_{2} \mathrm{O}_{2}$ content by 1.8 - and 2.1fold in shoot and 1.4- and 2.0-fold in root at $\mathrm{As}^{\mathrm{V}} 25$ and at $\mathrm{As}^{\mathrm{V}} 50$, respectively, than control. NO supplementation to $\mathrm{As}^{\mathrm{V}}$ stressed plants reduced the $\mathrm{H}_{2} \mathrm{O}_{2}$ accumulation by 35 and $16 \%$ in $\mathrm{NO}+\mathrm{As}^{\mathrm{V}} 25$ and 39 and $27 \%$ in $\mathrm{NO}+\mathrm{As}^{\mathrm{V}} 50$ in shoot and root, respectively, than corresponding $\mathrm{As}^{\mathrm{V}}$ alone exposed plants. As ${ }^{\mathrm{V}}$ stress also caused enhanced lipid peroxidation, measured in terms of MDA. The level of MDA enhanced to 2.3- and 2.6-fold in shoot and 1.5- and 2.0-fold in root with increase in $\mathrm{As}^{\mathrm{V}}$ exposure concentration $\left(\mathrm{As}^{\mathrm{V}} 25\right.$ and $\mathrm{As}^{\mathrm{V}} 50$ ) in comparison to control. NO supplementation to $\mathrm{As} \mathrm{V}$ stressed plants reduced the level of MDA significantly in both root and shoot than corresponding $\mathrm{As}^{\mathrm{V}}$ alone exposed plants (Figures 2A,B).

\section{Antioxidant Enzymes}

Arsenate stress has enhanced the SOD activity by ca. 1.9- and 2.2 -fold in shoot and ca. twofold and threefold in root in dose dependent manner than control. Supplementation of NO alone has no significant impact on SOD activity. NO supplementation to $\mathrm{As}{ }^{\mathrm{V}}$ stressed plants significantly reduced the SOD activity than corresponding $\mathrm{As}^{\mathrm{V}}$ alone treated plants (Figure 3A).

Nitric oxide treatment reduced CAT and GPX activity by 33 and $34 \%$, respectively, in root while no significant impact was observed in shoot in comparison to control. APX activity was also reduced by 29 and $46 \%$ in root and shoot, respectively, in $\mathrm{NO}$ treated plants than control. In $\mathrm{As}^{\mathrm{V}}$ stressed plants, CAT activity was enhanced ca. twofold and threefold in shoot and ca. 2.3- and 3.9-fold in root, and GPX activity was enhanced to 22 and $36 \%$ in shoot and 35 and $77 \%$ in root, at $\mathrm{As}^{\mathrm{V}} 25$ and $\mathrm{As}^{\mathrm{V}} 50$, respectively, than control. APX activity was also increased upon $\mathrm{As}^{\mathrm{V}}$ exposure both in root and shoot than control. NO supplementation to $\mathrm{As}^{\mathrm{V}}$ stressed plants resulted in significant reduction in the activities of CAT, APX, and GPX both in root and shoot than corresponding $\mathrm{As}^{\mathrm{V}}$ alone exposed plants (Figures 3B-D). In contrast, the activity of GR was enhanced both by $\mathrm{NO}$ and $\mathrm{As}{ }^{\mathrm{V}}$ alone treated plants both in root and shoot. However, NO supplementation to $\mathrm{As}^{\mathrm{V}}$ stressed plants, reduced the GR activity than $\mathrm{As}^{\mathrm{V}}$ alone stressed plants (Figure 3E).

Nitric oxide treatment has reduced the ascorbate content in shoot $(25 \%)$, while no significant change was observed in root than control. As ${ }^{\mathrm{V}}$ exposure also reduced the ascorbate content both in root and shoot in dose dependent manner. $\mathrm{NO}$ supplementation to $\mathrm{As}^{\mathrm{V}}$ stressed plants further reduced the ascorbate content in shoot, while in root it enhanced to control levels (Figure 3F).

Nitric oxide and $\mathrm{As}^{\mathrm{V}}$ alone has reduced the nitrite content in both root and shoot than control with more decline in root. NO treatment also reduced the NR activity to one fourth in root, while $\mathrm{As}{ }^{\mathrm{V}}$ stress enhanced the NR activity both in root and shoot in dose dependent manner than control. NO supplementation to $\mathrm{As}^{\mathrm{V}}$ stressed plants enhanced the nitrite content in shoot, while NR activity was reduced both in root and shoot than corresponding $\mathrm{As}^{\mathrm{V}}$ alone stressed plants both in root and shoot (Figures 3G,H).

TABLE 1 | Effect on shoot, root lengths (cm), fresh-weight $(\mathrm{g})$, total chlorophyll content (mg $\left.\mathrm{g}^{-1} \mathrm{fw}\right)$, and carotenoid content (mg $\left.\mathrm{g}^{-1} \mathrm{fw}\right)$ of rice after 7 days of treatment with different combinations of NO and Asv.

\begin{tabular}{|c|c|c|c|c|c|}
\hline Treatments & Root length & Shoot length & Biomass & Total Chlorophyll & Carotenoids \\
\hline Control & $4.18^{\mathrm{cd}} \pm 0.63$ & $30.56^{d} \pm 0.58$ & $0.33^{a b} \pm 0.10$ & $2.18^{\mathrm{C}} \pm 0.04$ & $0.153^{a} \pm 0.004$ \\
\hline NO & $4.50^{d} \pm 0.39$ & $35.52^{\mathrm{e}} \pm 1.21$ & $0.47^{b} \pm 0.09$ & $2.41^{d} \pm 0.08$ & $0.156^{a} \pm 0.004$ \\
\hline$A s^{\vee} 25$ & $3.13^{b} \pm 0.63$ & $24.78^{b} \pm 0.50$ & $0.21^{a} \pm 0.08$ & $1.69^{b} \pm 0.06$ & $0.160^{a} \pm 0.005$ \\
\hline $\mathrm{As}^{\mathrm{V}} 50$ & $2.25^{\mathrm{a}} \pm 0.29$ & $22.25^{\mathrm{a}} \pm 0.50$ & $0.15 a \pm 0.07$ & $1.40^{\mathrm{a}} \pm 0.11$ & $0.160^{a} \pm 0.004$ \\
\hline $\mathrm{NO}+\mathrm{As}^{\mathrm{V}} 25$ & $4.00^{b c d} \pm 0.45$ & $31.65^{d} \pm 0.90$ & $0.26^{a b} \pm 0.12$ & $2.32^{d} \pm 0.01$ & $0.159^{a} \pm 0.001$ \\
\hline $\mathrm{NO}+\mathrm{As}^{\mathrm{V}_{5}} 5$ & $3.50^{\mathrm{bc}} \pm 0.41$ & $28.50^{\mathrm{C}} \pm 1.29$ & $0.24^{a} \pm 0.17$ & $2.14^{\mathrm{C}} \pm 0.04$ & $0.156^{a} \pm 0.003$ \\
\hline
\end{tabular}

Values marked with same alphabets are not significantly different (DMRT, $p<0.05)$. All the values are means of five replicates $\pm S D$. 


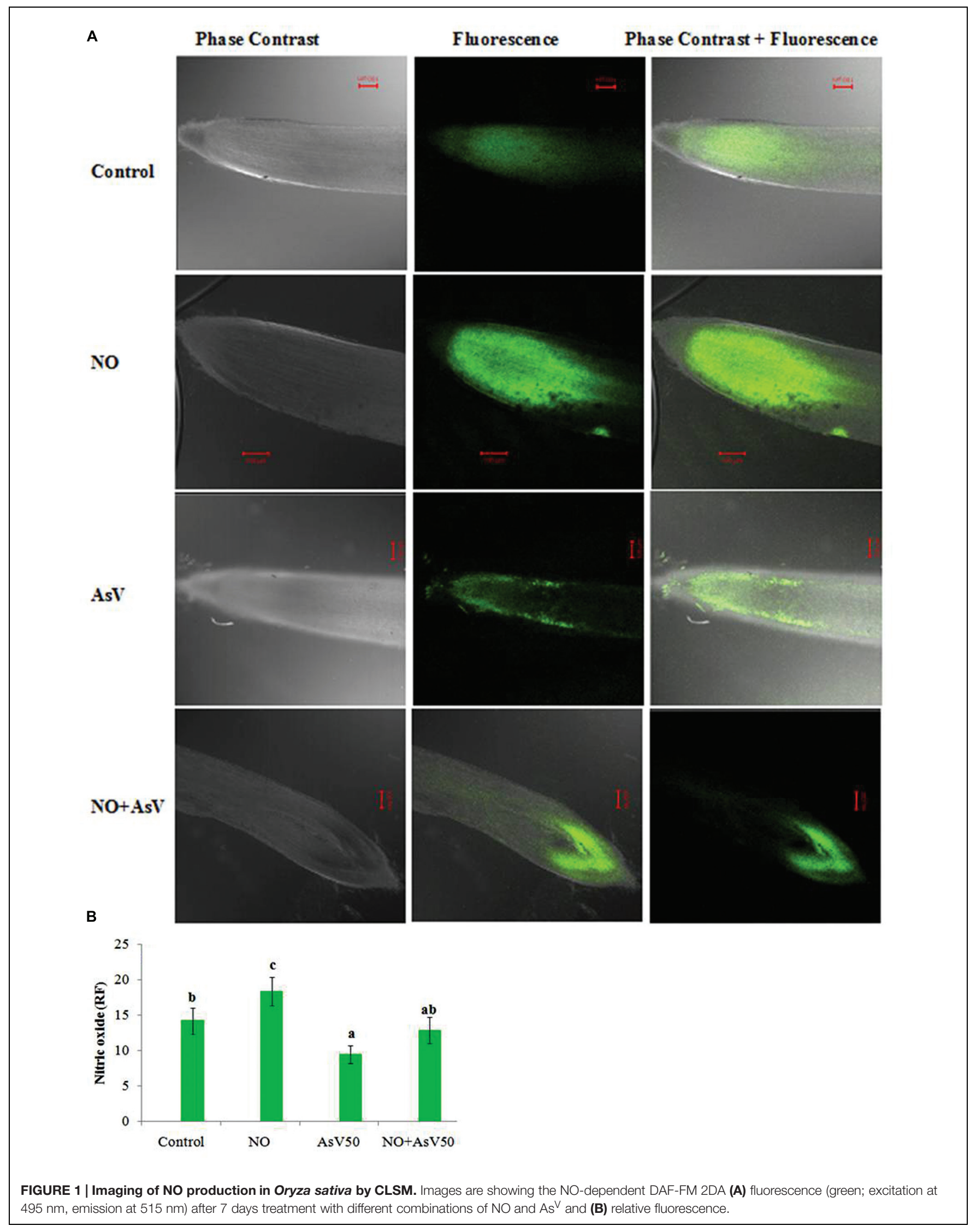



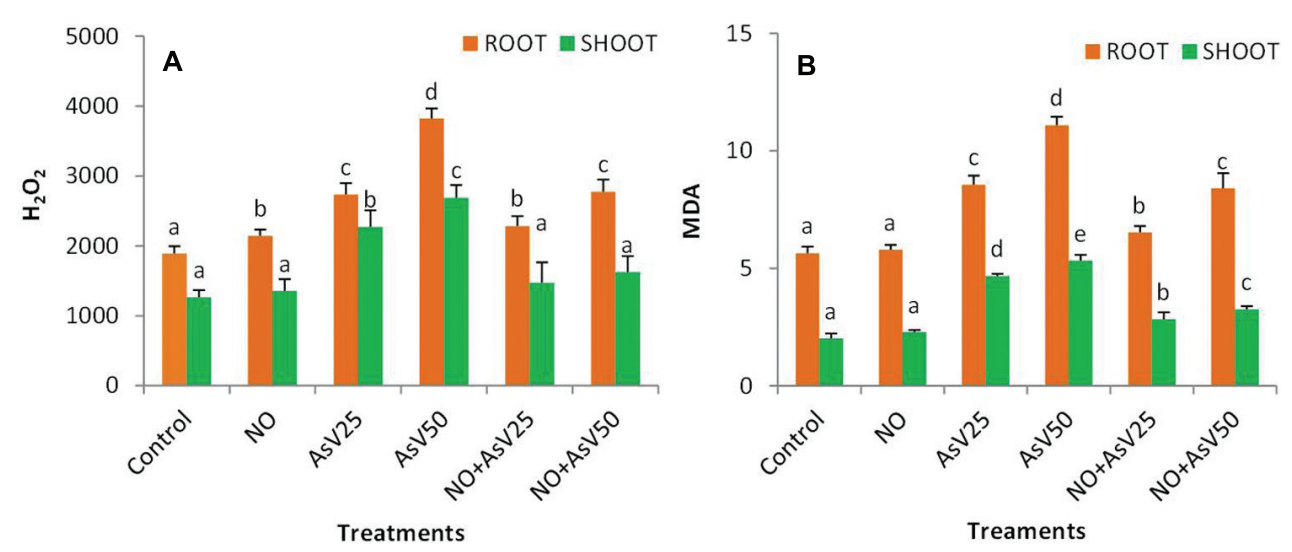

FIGURE 2 | Effect on (A) $\mathrm{H}_{2} \mathrm{O}_{2}$ (nMol g ${ }^{-1} \mathrm{fw}$ ) and (B) MDA (mMol $\mathrm{g}^{-1} \mathrm{fw}$ ) in the rice after 7 days of treatment with different combinations of As ${ }^{\mathbf{V}}$ and NO. Values marked with same alphabets are not significantly different (DMRT, $p<0.05$ ). All the values are mean of three replicates \pm SD.

\section{Thiol Metabolism}

Arsenate and NO alone treatment enhanced the cysteine content in both root and shoot in dose dependent manner than control. NO supplementation to $\mathrm{As}^{\mathrm{V}}$ stressed plants has reduced the cysteine content at higher $\mathrm{As}^{\mathrm{V}}$ concentration, i.e., at $50 \mu \mathrm{M}$, than corresponding $\mathrm{As}^{\mathrm{V}}$ alone stressed plants though it was still higher than control levels (Figure 4A). NO and $\mathrm{As}^{\mathrm{V}}$ treatment did not caused much changes in NPT level both in root and shoot than control. NO supplementation to $\mathrm{As}^{\mathrm{V}}$ stressed plants slightly reduced the NPT content than $\mathrm{As}^{\mathrm{V}}$ alone stressed plants (Figure 4B). Plants exposed to higher concentration of $\mathrm{As}^{\mathrm{V}}\left(\mathrm{As}^{\mathrm{V}} 50\right)$ has decrease the GSH content in both root and shoot significantly than control. Exposure to higher concentration of $\mathrm{As}^{\mathrm{V}}\left(\mathrm{As}^{\mathrm{V}} 50\right)$ has enhanced the GSSG level in both root and shoot, while the lower concentration ( $\left.\mathrm{As}^{\mathrm{V}} 25\right)$ enhanced the GSSG level only in root than control. NO supplementation to $\mathrm{As}^{\mathrm{V}}$ stressed plants has reduced the GSSG level both in root and shoot than alone $\mathrm{As}^{\mathrm{V}}$ exposed plants. $\mathrm{NO}$ treatment has no significant impact on GSH/GSSG ratio although $\mathrm{As}^{\mathrm{V}}$ has reduced the ratio significantly in dose dependent manner than control in both root and shoot, although, more reduction was observed in root than shoot. $\mathrm{NO}$ supplementation to $\mathrm{As}^{\mathrm{V}}$ stressed plants significantly enhanced the GSH/GSSG ratio than corresponding alone $\mathrm{As}^{\mathrm{V}}$ stressed plants (Figures $4 \mathrm{C}-\mathrm{E}$ ). NO treatment enhanced the PCs level by approximately $25 \%$ in both root and shoot than control plants. $\mathrm{As}^{\mathrm{V}}$ exposure also enhanced the PCs level significantly both in root and shoot in dose dependent manner. NO supplementation to $\mathrm{As} V$ significantly reduced the PCs level than alone $\mathrm{As}^{\mathrm{V}}$ stressed plants (Figure 4F).

Glutathione-S-transferase activity was reduced to approximately half in NO treated plants than control in both root and shoot. In $\mathrm{As}^{\mathrm{V}}$ exposed plants, GST activity was enhanced in dose dependent manner than in control in both the root and shoot. NO supplementation to $\mathrm{As}^{\mathrm{V}}$ stressed plants reduced the GST activity than alone $\mathrm{As}^{\mathrm{V}}$ stressed plants (Figure 5A). $\gamma$-ECS activity was enhanced by $\mathrm{As}^{\mathrm{V}}$ and $\mathrm{NO}$ both whether alone or in combination. NO treatment had more significant impact on $\gamma$-ECS activity (Figure 5B). Similar trend was observed for CS activity (Figure 5C).

\section{Element Accumulation}

Arsenate treatment has enhanced the Fe accumulation in root, but reduced in shoot in dose dependent manner. NO treatment has enhanced the $\mathrm{Fe}$ accumulation in root (17\%) and in shoot (25\%) than control. NO supplementation to $\mathrm{As}^{\mathrm{V}}$ stressed plants, enhanced the Fe accumulation in shoot than corresponding alone As stressed plants. As ${ }^{\mathrm{III}}$ exposed plants accumulated a significant amount of As in root and shoot. NO supplementation to $\mathrm{As}^{\mathrm{V}}$ stressed plants has reduced the As accumulation in root more $30 \%$ and in shoot more than $47 \%$ than corresponding alone $\mathrm{As} V$ exposed plants (Table 2).

\section{Arsenite and Fe Transporters}

Nitric oxide alone treatment has no significant impact on OsLsi1 and OsLsi2 expression level than control. $\mathrm{As}^{\mathrm{V}}$ exposure has enhanced the expression level of OsLsi1 and OsLsi2 in dose dependent manner than control. NO supplementation to $\mathrm{As}^{\mathrm{V}}$ stressed plants reduced the expression level of these transporters than corresponding alone $\mathrm{As}^{\mathrm{V}}$ exposed plants (Figures 6A,B).

The expression of OsYSL2 was enhanced upon NO treatment. $\mathrm{As}^{\mathrm{V}}$ also enhanced the expression of OsYSL2 in dose dependant manner with up to sevenfold higher expression at $\mathrm{As}^{\mathrm{V}} 50$. NO supplementation to $\mathrm{As}^{\mathrm{V}}$ stressed plants significantly reduced the expression level of OsYSL2 than corresponding alone $\mathrm{As} \mathrm{V}$ exposed plants and expression level was comparable to NO alone treated plants. Similar expression pattern was observed for OSIRT1. In contrast, the expression level of OsFRDL1 was reduced both by $\mathrm{NO}$ and $\mathrm{As}{ }^{\mathrm{V}}$ than control while $\mathrm{NO}$ supplementation to $\mathrm{As}^{\mathrm{V}}$ exposed plants enhanced the expression level than alone $\mathrm{As}^{\mathrm{V}}$ exposed plants. The expression of $\mathrm{OsIRO} 2$ was reduced by $\mathrm{NO}$ while it enhanced by $\mathrm{As}^{\mathrm{V}}$ exposure. When $\mathrm{NO}$ and $\mathrm{As}{ }^{\mathrm{V}}$ are provided in combination ( $\mathrm{NO}+\mathrm{As}$ ), expression level of OsIRO2 was decreased than corresponding alone $\mathrm{As}^{\mathrm{V}}$ stressed plants (Figures 6C-F) 


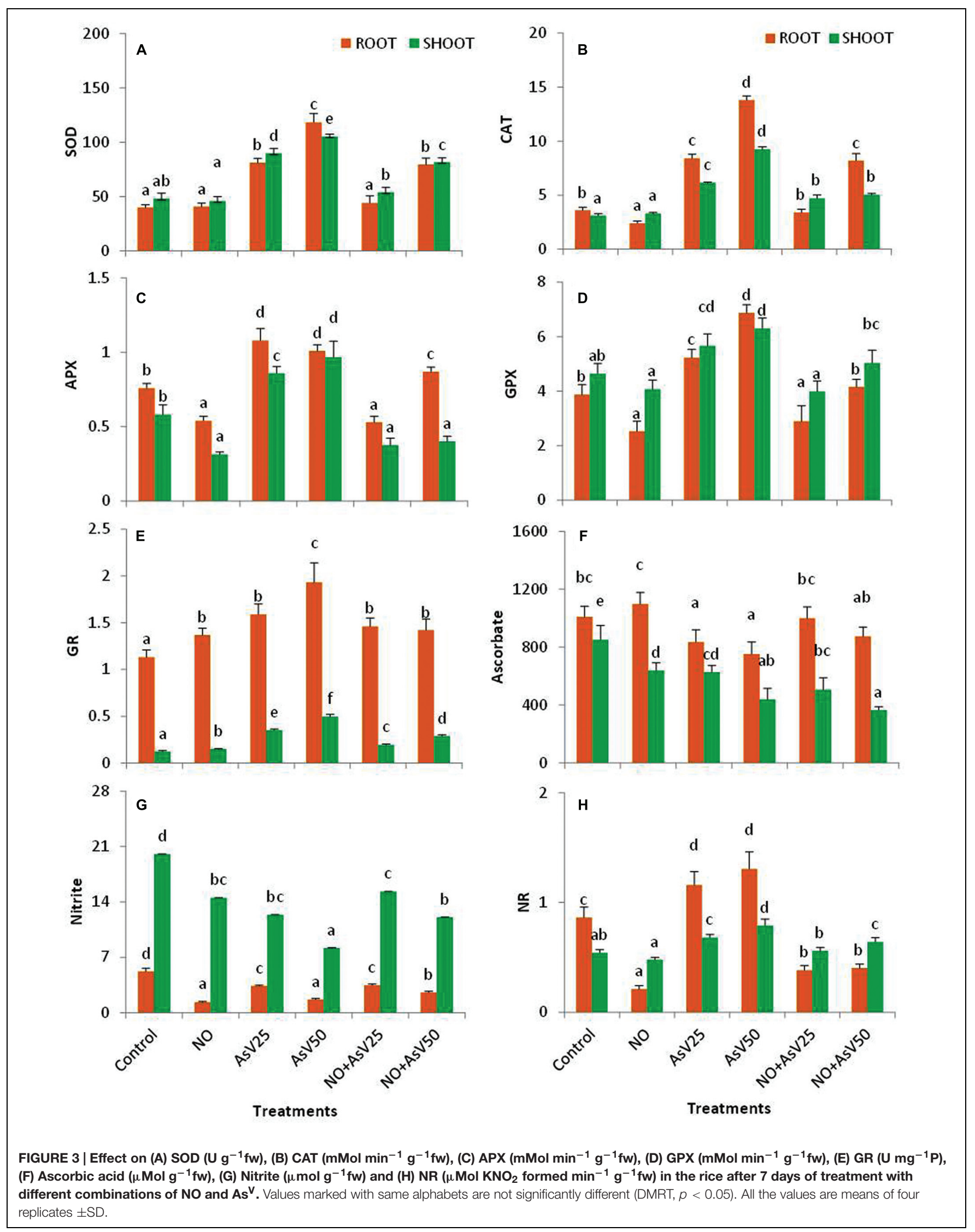




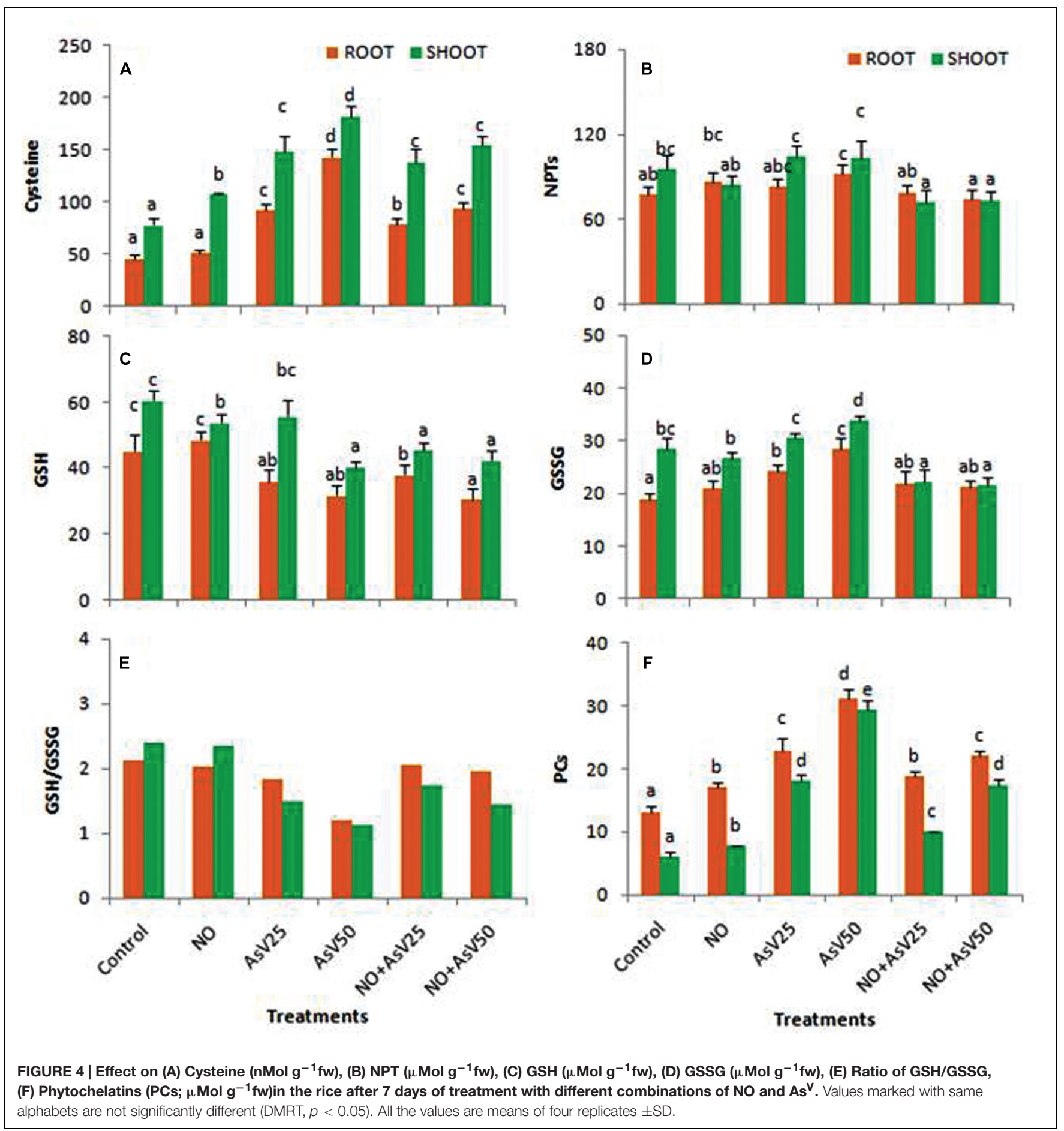

\section{DISCUSSION}

Nitric oxide is an important gaseous signaling molecule in plant system and has been reported to play a crucial role against various heavy metals (as detailed in Introduction). Present experiment is designed to investigate the protective role of NO during As stress.

Arsenic is well known to adversely affect the plant growth and development after its entry to plant system (Gupta et al., 2009;
Dixit et al., 2015c; Pandey and Gupta, 2015). In the hydroponic medium under anaerobic condition most of $\mathrm{As}^{\mathrm{V}}$ gets converted to $\mathrm{As}^{\mathrm{III}}$. Xu et al. (2007) observed that $97 \%$ of $\mathrm{As}^{\mathrm{V}}$ supplied in nutrient medium (hydroponic conditions) was converted to As ${ }^{\mathrm{III}}$ within $8 \mathrm{~h}$. So, in the present work, although $\mathrm{As}^{\mathrm{V}}$ was supplied in nutrient medium but transporters of $\mathrm{As}^{\mathrm{III}}$ were analyzed. In the present study, a significant amount of As was accumulated in rice plant on exposure to As and hampered the plant growth. NO 


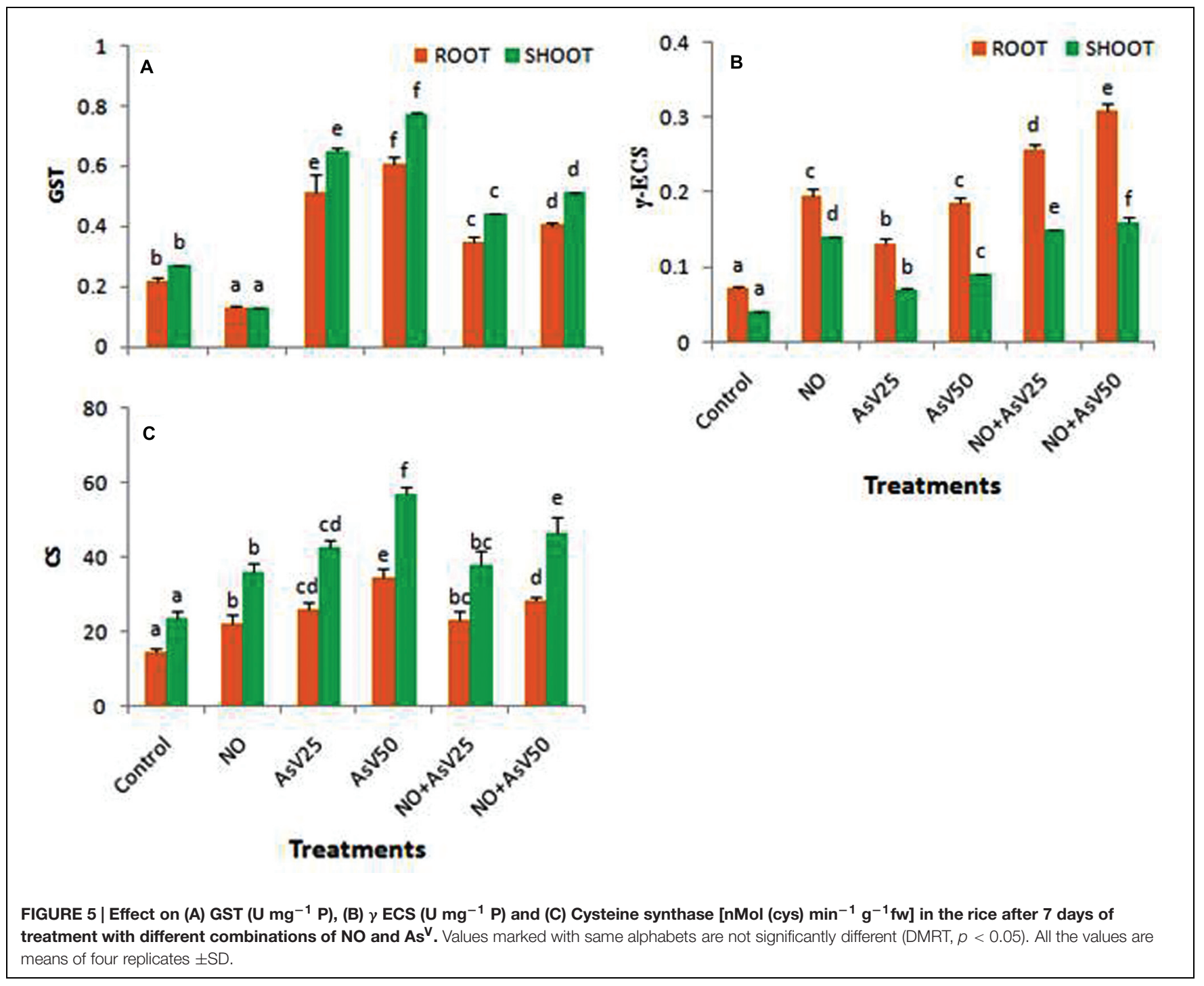

supplementation to $\mathrm{As}^{\mathrm{V}}$ stressed plants significantly reduced the As accumulation in both root and shoot. NO supplementation also reduced the As translocation from root to shoot. As induced enhanced expression of OsLsi1 and OsLsi2 was also reduced by NO. The transporter OsLsi1 and OsLsi2 are responsible

TABLE 2 | Accumulation ( $\mu \mathrm{g} \mathrm{g}^{-1} \mathrm{dw}$ ) of As and $\mathrm{Fe}$ in the roots and shoots of rice after 7 days of treatment with different combinations of NO and $\mathrm{As}^{\mathrm{V}}$.

\begin{tabular}{lcccr}
\hline Treatments & As Root & As Shoot & Fe Root & Fe Shoot \\
\hline Control & - & - & $265.1^{\mathrm{a}} \pm 26.4$ & $71.4^{\mathrm{cd}} \pm 5.6$ \\
$\mathrm{NO}$ & - & - & $311.2^{\mathrm{b}} \pm 22.8$ & $89.1^{\mathrm{e}} \pm 6.9$ \\
As $^{\vee} 25$ & $778.1^{\mathrm{b}} \pm 21.2$ & $86.8^{\mathrm{c}} \pm 3.8$ & $494.5^{\mathrm{d}} \pm 26.3$ & $57.8^{\mathrm{ab}} \pm 4.7$ \\
As $^{\vee} 50$ & $898.2^{\mathrm{c}} \pm 38.9$ & $92.9^{\mathrm{c}} \pm 8.6$ & $578.3^{\mathrm{e}} \pm 31.3$ & $51.3^{\mathrm{a}} \pm 4.8$ \\
NO + As $^{\vee} 25$ & $542.6^{\mathrm{a}} \pm 17.2$ & $39.0^{\mathrm{a}} \pm 2.1$ & $383.9^{\mathrm{c}} \pm 18.6$ & $79.9^{\mathrm{d}} \pm 2.2$ \\
NO + As $^{\vee}$ 50 & $582.5^{\mathrm{ab}} \pm 12.4$ & $49.1^{\mathrm{b}} \pm 2.7$ & $413.4^{\mathrm{c}} \pm 14.0$ & $66.3^{\mathrm{bc}} \pm 3.6$
\end{tabular}

Values marked with same alphabets are not significantly different (DMRT, $p<0.05)$. All the values are means of four replicates $\pm S D$. for $\mathrm{As}^{\mathrm{III}}$ internalization and its root to shoot translocation, respectively. Since As ${ }^{\mathrm{III}}$ is the dominant form inside the plant (Tripathi et al., 2007; Singh et al., 2015) and also probably the main As species translocated to the shoots. Therefore, down regulation of OsLsi1 and OsLsi2 would negatively affect the As accumulation. From correlation analysis between expression of OsLsi1 and As accumulation in root $(R=0.85)$, it is evident that down regulation of OsLsi1 must be responsible for reduced As accumulation in root. But the correlation value between As accumulation in shoot and expression level of OsLsi2 is relatively less significant $(R=0.53)$. $\mathrm{NO}$ is also reported to activate the ABC transporters (Grün et al., 2006). The ABC transporters are responsible for vacuolar sequestration of As(III)-PC complexes (Song et al., 2010). So it might be possible that in NO treated plants, most of As accumulated in rice root was sequestered in root vacuole in the form of As(III)-PC complex and less As is transported to shoot. Further in the present study, NO treatment also enhanced the PCs synthesis. Since less accumulation of As in shoot might also affect its accumulation in grain which 

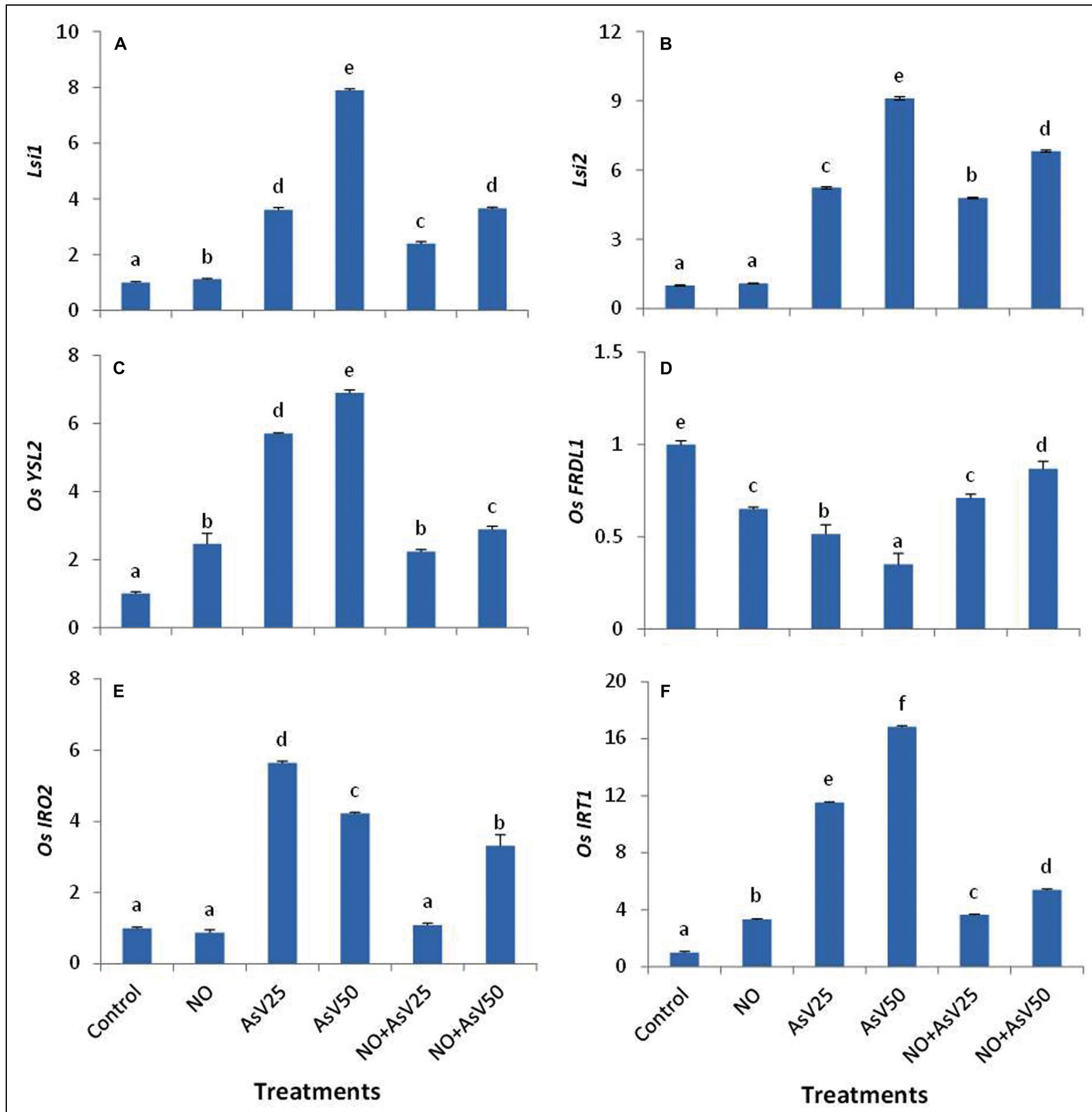

FIGURE 6 | Relative expression of (A) OsLsi1, (B) OsLsi2, (C) OsYSL2, (D) OsFRDL1, (E) OsIRO2, and (F) OsIRT1 in the rice root after 7 days of treatment with different combinations of NO and $\mathbf{A} \mathbf{s}^{\mathbf{V}}$. Values marked with same alphabets are not significantly different (DMRT, $\left.p<0.05\right)$. All the values are means of four replicates $\pm S D$.

would have great implications with respect to As toxicity in food chain. NO mediated reduced accumulation of As in rice root and coleoptiles was previously reported by Singh et al. (2009).

In the present study, NO enhanced the plant growth in terms of root, shoot length, and biomass. NO serves as positive growth regulator in plant. Recent research has established that
NO is a phytohormone that influences diverse physiological processes in plants (Takahashi and Morikawa, 2014). Low concentration of exogenously supplied NO enhances the plant growth, whereas, no promotive effect was observed at higher concentrations (Leshem, 1996). NO supplementation to $\mathrm{As}^{\mathrm{V}}$ stressed plants partially restored the plant growth. Previously, Tian and Lei (2006) showed that low concentration of NO 
promotes the growth of wheat, while high concentration has no significant impact. In the present study, NO supplementation to $\mathrm{As}^{\mathrm{V}}$ stressed plants overcame $\mathrm{As}{ }^{\mathrm{V}}$ mediated root hairs growth inhibition. It has been previously reported that NO induces the adventitious root development by means of auxin in cucumber (Pagnussat et al., 2002). NO mediated protective effect previously reported in sunflower against Cd stress (Laspina et al., 2005) and in rice against As stress (Singh et al., 2009). In the present study, a significant loss of chlorophyll was observed in $\mathrm{As}^{\mathrm{V}}$ stressed plants as previously reported in rice (Singh et al., 2015). In the present study, NO supplementation to $\mathrm{As}^{\mathrm{V}}$ stressed plants reverted As mediated chlorophyll loss. Exogenous NO treatment has been reported to retard the chlorophyll degradation (Eum et al., 2009). This might be the reason for enhanced chlorophyll upon NO supplementation in $\mathrm{As}^{\mathrm{V}}$ treated plants. NO mediated enhancement of chlorophyll has been reported in maize (Graziano et al., 2002) and in lettuce (Beligni and Lamattina, 2000). Carotenoids content was found relatively unaltered by exogenous application of $\mathrm{NO}$ or $\mathrm{As}^{\mathrm{V}}$. In the present study $\mathrm{As}^{\mathrm{V}}$ also reduced the $\mathrm{Fe}$ content in shoot that may also be responsible for $\mathrm{As}^{\mathrm{V}}$ mediated chlorosis, while NO has enhanced the iron content in shoot and reverted the chlorosis. It has been previously reported by Graziano and Lamattina (2007) in tomato that exogenous NO improved the plant growth under Fe deficient conditions by modulation of expression of $\mathrm{Fe}$ uptake related genes and by regulation of physiological and morphological adaptive responses. Rice plant belongs to family Poaceae and follows the Strategy II for Fe uptake (Kobayashi and Nishizawa, 2012). OsYSL2 is responsible for long distance transport of $\mathrm{Fe}(\mathrm{II})-\mathrm{NA}$ (NA, nicotianamine) and $\mathrm{Mn}$ (II)-NA complex to sink tissue (Koike et al., 2004). In the present study, NO treated plants enhanced OsYSL2 expression level while in $\mathrm{As}^{\mathrm{V}}$ treated plants it was down regulated. Corresponding changes were observed in $\mathrm{Fe}$ accumulation in shoot. OsFRDL1 is expressed in root pericycle and also responsible for long distance transport of Fe (Yokosho et al., 2009). OsFRDL1 is citrate efflux transporter. This citrate serves as $\mathrm{Fe}$ chelator and forms Fe-chelate, which is transported to plant root by different Fe transporters. So, OsFRDL1 is not directly involve in $\mathrm{Fe}$ transport but facilitates $\mathrm{Fe}$ transport (Kobayashi and Nishizawa, 2012). OsFRDL1 was down regulated both in NO and $\mathrm{As}^{\mathrm{V}}$ treated plants. OsFRDL1 mutants show only mild symptoms of Fe deficiency that suggest that there are alternate chelators for xylem Fe transport (Kobayashi and Nishizawa, 2012). In the present study, there was no correlation between Fe accumulation and transcript level of OsFRDL1. OsIRO2 is positive transcription regulator and regulates various other genes related to Fe uptake (Kobayashi and Nishizawa, 2012) and induced by $\mathrm{Fe}$ deficiency. In the present study, $\mathrm{As}^{\mathrm{V}}$ treatment induced Fe deficiency in shoot while the transcript levels of OsIRO2 increased, probably to increase Fe acquisition. Rice despite being a Strategy II plant, have OsIRT1 that allows this plant to absorb $\mathrm{Fe}^{+2}$ that is predominant form of iron under anaerobic and submerged conditions. In NO treated plants, OsIRT1 level was enhanced also previously reported by Koen et al. (2012) in Arabidopsis. In $\mathrm{As}^{\mathrm{V}}$ treated plants
Fe accumulation in root and transcript level of OsIRT1 were enhanced.

In the present study, $\mathrm{As}^{\mathrm{V}}$ exposure enhanced oxidative stress that was evident by increased level of ROS, MDA, and $\mathrm{H}_{2} \mathrm{O}_{2}$, however, NO supplementation to $A \mathrm{~s}^{\mathrm{V}}$ stressed plants showed a protection against oxidative stress and decreased the level of ROS, $\mathrm{H}_{2} \mathrm{O}_{2}$, and MDA. Similar results were reported by Singh et al. (2009) in rice. NO is stable radical but it can react with other radical such as ROS and can neutralize them (Hill et al., 2010). In the present study, NO might have neutralized ROS and $\mathrm{H}_{2} \mathrm{O}_{2}$, therefore, less membrane damage and reduced MDA. Decreased level of As in root and shoot in $\mathrm{NO}$ supplemented $\mathrm{As}^{\mathrm{V}}$ stressed plants may also responsible for reduced oxidative stress beyond the NO mediated antioxidant action.

In the present study, $A s^{\mathrm{V}}$ exposure caused a significant reduction in NO dependent fluorescence or endogenous level of NO. A similar decrease in NO dependent fluorescence under Cd stress was also observed in shoot (Rodríguez-Serrano et al., 2009), however, Besson-Bard et al. (2009) reported enhancement in NO dependent fluorescence in both root and shoot in Arabidopsis thaliana under Cd stress. During heavy metal exposure endogenous level of NO may increase or decrease depends upon plant species and experimental setup (Arasimowicz-Jelonek et al., 2011). Reduced level of NO in root was also found to correlate with enhanced level of ROS. It again justifies the antioxidant behavior of NO.

Superoxide dismutase activity was enhanced under $\mathrm{As}^{\mathrm{V}}$ stress as previously reported by Kumar et al. (2013). NO supplementation to $\mathrm{As}^{\mathrm{V}}$ stressed plants also reduced the SOD activity. Similar results were previously reported by Singh et al. (2009). APX, GPX, and CAT play a crucial role in $\mathrm{H}_{2} \mathrm{O}_{2}$ degradation. Under $\mathrm{As}^{\mathrm{V}}$ stress, activity of these enzymes was enhanced due to enhanced level of $\mathrm{H}_{2} \mathrm{O}_{2}$. There are contrasting reports on influence of $\mathrm{NO}$ on CAT activity. In tobacco plants, NO was reported to inhibit the CAT activity (Clark et al., 2000), while in wheat NO treatment has enhanced the CAT activity (Sun et al., 2014). In the present study, NO treatment has enhanced the CAT activity. This contrasting behavior in CAT activity may be due to use of different NO donors, (Clark et al., 2000) used SNAP ( $S$-Nitroso- $N$-Acetyl-D,L-Penicillamine) and GSNO ( $S$-nitrosoglutathione) as NO donor while (Sun et al., 2014) and in the present study SNP used as NO donor.

Cysteine is precursor of GSH and $\gamma$-ECS is rate limiting enzyme of GSH biosynthesis (Xiang and Oliver, 1998). In $\mathrm{As}^{\mathrm{V}}$ stressed plants, cysteine content and $\gamma$-ECS activity were enhanced that indicates the enhanced synthesis of GSH. Our results of GSH estimation also conferred the enhance level of GSH. NO treatment also enhanced the cysteine and $\gamma$-ECS. NO mediated enhancement of $\gamma$-ECS has been reported in Medicago by Innocenti et al. (2007). CS, involved at final step of cysteine synthesis, was directly correlated with the level of cysteine ( $R=0.94$ in root and $R=0.96$ in shoot). GSH protects the cell from free metal ions by forming nontoxic complexes and facilitates their sequestration and GST catalyzes these conjugations (Jozefczak et al., 2012). In $\mathrm{As}^{\mathrm{V}}$ 
stressed plants activity of GST enhanced. Previously, enhanced activity of GST was reported in Arabidopsis after $\mathrm{Cu}$ and $\mathrm{Cd}$ treatment in order to stimulate free metal binding (Jozefczak et al., 2012).

Ascorbate and reduced glutathione are important antioxidant molecules in plant system and indicates the redox state of cell. They serve as redox buffering agents in protoplast and protect the plasma membrane from oxidation (Innocenti et al., 2007). GSH/GSSG ratio is also important for maintaining redox state of the cell (Dixit et al., 2015b). In the present study, under higher dose of $\mathrm{As}^{\mathrm{V}}$ stressed plants GSH/GSSG ratio was declined, while $\mathrm{NO}$ supplementation to $\mathrm{As}^{\mathrm{V}}$ stressed plants resumed this ratio. Glutathione reductase plays a crucial role in maintaining the ratio of GSH/GSSG by converting GSSG to GSH. Despite of decreased ratio of GSH/GSSG, GR activity was enhanced in $\mathrm{As}^{\mathrm{V}}$ stressed plants. It suggests that metal induced stimulation of GR was not sufficient to cope up with massive GSH consuming effects of metal, such as direct metal GSH binding, GSH oxidation, and PCs synthesis (Jozefczak et al., 2012). NO treatment also decreased the GSH level in shoot while GSH/GSSG ratio remained unchanged, therefore, lowered GSH level probably not attributed to oxidative stress but it may be a consequence of GSH nitrosylation (de Pinto et al., 2002). Ascorbate content also reduced under $\mathrm{As}^{\mathrm{V}}$ stress and in NO treated plants. Reduced level of Asc under As stress is previously reported by Kumar et al. (2013).

Nitrate reductase activity enhanced under $\mathrm{As}^{\mathrm{V}}$ stress as previously reported by Singh et al. (2015), but in NO treated plants, irrespective of presence of $\mathrm{As}{ }^{\mathrm{V}}, \mathrm{NR}$ activity was greatly diminished. In $\mathrm{As}^{\mathrm{V}}$ stressed plants despite of enhanced NR activity there was no corresponding increase observed in nitrite level. The possible explanation for this may be that $\mathrm{NO}$ is directly serving as antioxidant and higher NO synthesized due to enhanced activity of NR got consumed in neutralization of free radicals produced due to $\mathrm{As}^{\mathrm{V}}$, while during exogenous supplementation of $\mathrm{NO}$, plants have stopped endogenous synthesis of NO.

\section{REFERENCES}

Arasimowicz-Jelonek, M., Floryszak-Wieczorek, J., and Gwóźdź, E. A. (2011). The message of nitric oxide in cadmium challenged plants. Plant Sci. 181, 612-620. doi: 10.1016/j.plantsci.2011.03.019

Arnon, D. I. (1949). Copper enzymes in isolated chloroplasts. Polyphenoloxidase in Beta vulgaris. Plant Physiol. 24, 1-15. doi: 10.1104/pp.24.1.1

Beauchamp, C., and Fridovich, I. (1971). Superoxide dismutase: improved assays and an assay applicable to acrylamide gels. Anal. Biochem. 44, 276-287. doi: 10.1016/0003-2697(71)90370-8

Beligni, M. V., and Lamattina, L. (2000). Nitric oxide stimulates seed germination and de-etiolation, and inhibits hypocotyl elongation, three light-inducible responses in plants. Planta 210, 215-221. doi: 10.1007/PL00008128

Bellin, D., Asai, S., Delledonne, M., and Yoshioka, H. (2013). Nitric oxide as a mediator for defense responses. Mol. Plant Microbe Interact. 26, 271-277. doi: 10.1094/MPMI-09-12-0214-CR

Besson-Bard, A., Gravot, A., Richaud, P., Auroy, P., Duc, C., Gaymard, F., et al. (2009). Nitric oxide contributes to cadmium toxicity in Arabidopsis by

\section{CONCLUSION}

Nitric oxide ameliorated the As toxicity in rice by modulating antioxidant system and thiol metabolism. NO supplementation also significantly reduced the As accumulation in root and shoot and modulated the gene expression level of As ${ }^{\mathrm{III}}$ transporters (OsLsi1 and OsLsi2). As and NO affected the GSH metabolism both at biosynthesis, i.e., cysteine, and consumption, i.e., PC and altered GSSG/GSH balance.

\section{AUTHOR CONTRIBUTIONS}

RT, DC, PT, PS, VP, SM ${ }^{1}$, and OD designed experiments and reviewed manuscript. AS and GD performed experimental work and prepared figures. $\mathrm{AS}$ and $\mathrm{SM}^{2}$ prepared the manuscript. AK and SD helped in elemental analysis. AK did data analysis. All authors have read and approved the manuscript.

$\mathrm{SM}^{1}$, Shekhar Mallick; $\mathrm{SM}^{2}$, Seema Mishra.

\section{ACKNOWLEDGMENTS}

The authors are thankful to Director, CSIR-National Botanical Research Institute (CSIR-NBRI), Lucknow for the facilities and for the financial support from the network projects (CSIRINDEPTH), New Delhi, India. APS is thankful to University Grant Commission, New Delhi, India and GD is thankful to CSIR, New Delhi for the award of Junior/Senior Research Fellowship and Academy of Scientific and Innovative Research (AcSIR) for his Ph.D. registration. Award of Fast Track Scientist to SM from DST is gratefully acknowledged. Award of Emeritus scientist (CSIR) project to RDT is gratefully acknowledged.

\section{SUPPLEMENTARY MATERIAL}

The Supplementary Material for this article can be found online at: http://journal.frontiersin.org/article/10.3389/fpls.2015.01272

promoting cadmium accumulation in roots and by up-regulating genes related to iron uptake. Plant Physiol. 149, 1302-1315. doi: 10.1104/pp.108.133348

Clark, D., Durner, J., Navarre, D. A., and Klessig, D. F. (2000). Nitric oxide inhibition of tobacco catalase and ascorbate peroxidase. Mol. Plant Microbe Interact. 13, 1380-1384. doi: 10.1094/MPMI.2000.13.12.1380

de Pinto, M. C., Tommasi, F., and De Gara, L. (2002). Changes in the antioxidant systems as part of the signaling pathway responsible for the programmed cell death activated by nitric oxide and reactive oxygen species in tobacco Bright-Yellow 2 cells. Plant Physiol. 130, 698-708. doi: 10.1104/pp.005629

Dixit, G., Singh, A. P., Kumar, A., Mishra, S., Dwivedi, S., Kumar, S., et al. (2015a). Reduced arsenic accumulation in rice (Oryza sativa L.) shoot involves sulfur mediated improved thiol metabolism, antioxidant system and altered arsenic transporters. Plant Physiol. Biochem. 99, 86-96. doi: 10.1016/j.plaphy.2015.11.005

Dixit, G., Singh, A. P., Kumar, A., Singh, P. K., Kumar, S., Dwivedi, S., et al. (2015b). Sulfur mediated reduction of arsenic toxicity involves efficient thiol metabolism and the antioxidant defense system in rice. J. Hazard. Mater. 298, 241-251. doi: 10.1016/j.jhazmat.2015.06.008 
Dixit, G., Singh, A. P., Kumar, A., Dwivedi, S., Deeba, F., and Tripathi, R. D. (2015c). Sulfur alleviates arsenic toxicity by reducing its accumulation and modulating proteome, amino acids and thiol metabolism in rive leaves. Sci. Rep. 5, 16205. doi: 10.1038/srep 16205

Duan, G. L., Hu, Y., Liu, W. J., Kneer, R., Zhao, F. J., and Zhu, Y. G. (2011). Evidence for a role of phytochelatins in regulating arsenic accumulation in rice grain. Environ. Exp. Bot. 71, 416-421. doi: 10.1016/j.envexpbot.2011.02.016

Duxbury, A. C., and Yentsch, C. S. (1956). Plankton pigment nomographs. J. Mar. Res. 15, 92-101.

Ellman, G. L. (1959). Tissue sulfhydryl groups. Arch. Biochem. Biophys. 82, 70-77. doi: 10.1016/0003-9861(59)90090-6

Eum, H. L., Hwang, D. K., and Lee, S. K. (2009). Nitric oxide reduced chlorophyll degradation in broccoli (Brassica oleracea L. var. italica) florets during senescence. Food Sci. Technol. Int. 15, 223-228. doi: 10.1177/1082013208339706

Finnegan, P. M., and Chen, W. (2012). Arsenic toxicity: the effects on plant metabolism. Front. Physiol. 3:182. doi: 10.3389/fphys.2012.00182

Gaitonde, M. K. (1967). A spectrophotometric method for the direct determination of cysteine in the presence of other naturally occurring amino acids. Biochem. J. 104, 627-633. doi: 10.1042/bj1040627

Graziano, M., Beligni, M. V., and Lamattina, L. (2002). Nitric oxide improves internal iron availability in plants. Plant Physiol. 130, 1852-1859. doi: 10.1104/pp.009076

Graziano, M., and Lamattina, L. (2007). Nitric oxide accumulation is required for molecular and physiological responses to iron deficiency in tomato roots. Plant J. 52, 949-960. doi: 10.1111/j.1365-313X.2007.03283.x

Grossi, L., and D'Angelo, S. (2005). Sodium nitroprusside: mechanism of NO release mediated by sulfhydryl-containing molecules. J. Med. Chem. 48, 26222626. doi: $10.1021 / \mathrm{jm} 049857 \mathrm{n}$

Groß, F., Durner, J., and Gaupels, F. (2013). Nitric oxide, antioxidants and prooxidants in plant defence responses. Front. Plant Sci. 4:419. doi: 10.3389/fpls.2013.00419

Grün, S., Lindermayr, C., Sell, S., and Durner, J. (2006). Nitric oxide and gene regulation in plants. J. Exp. Bot. 57, 507-516. doi: 10.1093/jxb/erj053

Gupta, M., and Ahmad, M. A. (2014). Arsenate induced differential response in rice genotypes. Ecotoxicol. Environ. Saf. 107, 46-54. doi: 10.1016/j.ecoenv.2014.04.030

Gupta, M., Sharma, P., Sarin, N. B., and Sinha, A. K. (2009). Differential response of arsenic stress in two varieties of Brassica juncea L. Chemosphere 74, 1201-1208. doi: 10.1016/j.chemosphere.2008.11.023

Habig, W. H., and Jakoby, W. B. (1981). Assays for differentiation of glutathione S-transferases. Methods Enzymol. 77, 398-405. doi: 10.1016/S00766879(81)77053-8

Hageman, R. H., and Reed, A. J. (1980). Nitrate reductase from higher plants. Methods Enzymol. 69, 270-280. doi: 10.1016/S0076-6879(80) 69026-0

Heath, R. L., and Packer, L. (1968). Photoperoxidation in isolated chloroplasts: I. Kinetics and stoichiometry of fatty acid peroxidation. Arch. Biochem. Biophys. 125, 189-198. doi: 10.1016/0003-9861(68)90654-1

Hill, B. G., Dranka, B. P., Bailey, S. M., Lancaster, J. R., and Darley-Usmar, V. M. (2010). What part of NO don't you understand? Some answers to the cardinal questions in nitric oxide biology. J. Biol. Chem. 285, 19699-19704. doi: $10.1074 /$ jbc.R110.101618

Hissin, P. J., and Hilf, R. (1976). A fluorometric method for determination of oxidized and reduced glutathione in tissues. Anal. Biochem. 74, 214-226. doi: 10.1016/0003-2697(76)90326-2

Innocenti, G., Pucciariello, C., Le Gleuher, M., Hopkins, J., de Stefano, M., Delledonne, M., et al. (2007). Glutathione synthesis is regulated by nitric oxide in Medicago truncatula roots. Planta 225, 1597-1602. doi: 10.1007/s00425-0060461-3

Ishimaru, Y., Masuda, H., Bashir, K., Inoue, H., Tsukamoto, T., Takahashi, M., et al. (2010). Rice metal-nicotianamine transporter, OsYSL2, is required for the long-distance transport of iron and manganese. Plant J. 62, 379-390. doi: 10.1111/j.1365-313X.2010.04158.x

Jozefczak, M., Remans, T., Vangronsveld, J., and Cuypers, A. (2012). Glutathione is a key player in metal-induced oxidative stress defenses. Int. J. Mol. Sci. 13, 3145-3175. doi: 10.3390/ijms13033145

Kato, M., and Shimizu, S. (1987). Chlorophyll metabolism in higher plants. VII. Chlorophyll degradation in senescing tobacco leaves; phenolic-dependent peroxidative degradation. Can. J. Bot. 65, 729-735. doi: 10.1139/ b87-097

Kobayashi, T., and Nishizawa, N. K. (2012). Iron uptake, translocation, and regulation in higher plants. Annu. Rev. Plant Biol. 63, 131-152. doi: 10.1146/annurev-arplant-042811-105522

Koen, E., Szymańska, K., Klinguer, A., Dobrowolska, G., Besson-Bard, A., and Wendehenne, D. (2012). Nitric oxide and glutathione impact the expression of iron uptake-and iron transport-related genes as well as the content of metals in A. thaliana plants grown under iron deficiency. Plant Signal. Behav. 7, 1246-1250. doi: 10.4161/psb.21548

Koike, S., Inoue, H., Mizuno, D., Takahashi, M., Nakanishi, H., Mori, S., et al. (2004). OsYSL2 is a rice metal-nicotianamine transporter that is regulated by iron and expressed in the phloem. Plant J. 39, 415-424. doi: 10.1111/j.1365313X.2004.02146.x

Kumar, A., Dwivedi, S., Singh, R. P., Chakrabarty, D., Mallick, S., Trivedi, P. K., et al. (2014a). Evaluation of amino acid profile in contrasting arsenic accumulating rice genotypes under arsenic stress. Biol. Plant. 58, 733-742. doi: 10.1007/s10535-014-0435-4

Kumar, A., Singh, R. P., Singh, P. K., Awasthi, S., Chakrabarty, D., Trivedi, P. K., et al. (2014b). Selenium ameliorates arsenic induced oxidative stress through modulation of antioxidant enzymes and thiols in rice (Oryza sativa L.). Ecotoxicology 23, 1153-1163. doi: 10.1007/s10646-014-1257-z

Kumar, N., Mallick, S., Yadava, R. N., Singh, A. P., and Sinha, S. (2013). Coapplication of selenite and phosphate reduces arsenite uptake in hydroponically grown rice seedlings: toxicity and defence mechanism. Ecotoxicol. Environ. Saf. 91, 171-179. doi: 10.1016/j.ecoenv.2013.01.027

Kumar, S., Dubey, R. S., Tripathi, R. D., Chakrabarty, D., and Trivedi, P. K. (2015). Omics and biotechnology of arsenic stress and detoxification in plants: current updates and prospective. Environ. Int. 74, 221-230. doi: 10.1016/j.envint.2014.10.019

Lamattina, L., García-Mata, C., Graziano, M., and Pagnussat, G. (2003). Nitric oxide: the versatility of an extensive signal molecule. Annu. Rev. Plant Biol. 54, 109-136. doi: 10.1146/annurev.arplant.54.031902.134752

Laspina, N. V., Groppa, M. D., Tomaro, M. L., and Benavides, M. P. (2005). Nitric oxide protects sunflower leaves against Cd-induced oxidative stress. Plant Sci. 169, 323-330. doi: 10.1016/j.plantsci.2005.02.007

Leshem, Y. Y. (1996). Nitric oxide in biological systems. Plant Growth Regul. 18, 155-159. doi: 10.1007/BF00024375

Livak, K. J., and Schmittgen, T. D. (2001). Analysis of relative gene expression data using real-time quantitative PCR and the 2- $\Delta \Delta$ CT method. Methods 25, 402-408. doi: 10.1006/meth.2001.1262

Lum, H. K., Lee, C. H., Butt, Y. K. C., and Lo, S. C. L. (2005). Sodium nitroprusside affects the level of photosynthetic enzymes and glucose metabolism in Phaseolus aureus (mung bean). Nitric Oxide 12, 220-230. doi: 10.1016/j.niox.2005. 03.002

Ma, J. F., Yamaji, N., Mitani, N., Xu, X. Y., Su, Y. H., McGrath, S. P., et al. (2008). Transporters of arsenite in rice and their role in arsenic accumulation in rice grain. Proc. Natl. Acad. Sci. U.S.A. 105, 9931-9935. doi: 10.1073/pnas.0802361105

Mallick, S., Kumar, N., Singh, A. P., Sinam, G., Yadav, R. N., and Sinha, S. (2013). Role of sulfate in detoxification of arsenate-induced toxicity in Zea mays L.(SRHM 445): nutrient status and antioxidants. J. Plant Interact. 8, 140-154. doi: 10.1080/17429145.2012.734863

McCarty, K. M., Hanh, H. T., and Kim, K. W. (2011). Arsenic geochemistry and human health in South East Asia. Rev. Environ. Health 26, 71-78. doi: 10.1515/reveh.2011.010

Mur, L. A., Mandon, J., Persijn, S., Cristescu, S. M., Moshkov, I. E., Novikova, G. V., et al. (2013). Nitric oxide in plants: an assessment of the current state of knowledge. AoB Plants 5:pls052. doi: 10.1093/aobpla/pls052

Murgia, I., Delledonne, M., and Soave, C. (2002). Nitric oxide mediates ironinduced ferritin accumulation in Arabidopsis. Plant J. 30, 521-528. doi: 10.1046/j.1365-313X.2002.01312.x

Nakano, Y., and Asada, K. (1981). Hydrogen peroxide is scavenged by ascorbatespecific peroxidase in spinach chloroplasts. Plant Cell Physiol. 22, 867-880.

Ogo, Y., Nakanishi Itai, R., Nakanishi, H., Kobayashi, T., Takahashi, M., Mori, S., et al. (2007). The rice bHLH protein OsIRO2 is an essential regulator of the genes involved in Fe uptake under Fe-deficient conditions. Plant J. 51, 366-377. doi: 10.1111/j.1365-313X.2007.03149.x 
Pagnussat, G. C., Simontacchi, M., Puntarulo, S., and Lamattina, L. (2002). Nitric oxide is required for root organogenesis. Plant Physiol. 129, 954-956. doi: $10.1104 /$ pp.004036

Pandey, C., and Gupta, M. (2015). Selenium and auxin mitigates arsenic stress in rice (Oryza sativa L.) by combining the role of stress indicators, modulators and genotoxicity assay. J. Hazard. Mater. 287, 384-391. doi: 10.1016/j.jhazmat.2015.01.044

Rodríguez-Serrano, M., Romero-Puertas, M. C., Pazmiño, D. M., Testillano, P. S., Risueño, M. C., Luis, A., et al. (2009). Cellular response of pea plants to cadmium toxicity: cross talk between reactive oxygen species, nitric oxide, and calcium. Plant Physiol. 150, 229-243. doi: 10.1104/pp.108.131524

Rodríguez-Serrano, M., Romero-Puertas, M. C., Zabalza, A. N. A., Corpas, F. J., Gómez, M., Del Rio, L. A., et al. (2006). Cadmium effect on oxidative metabolism of pea (Pisum sativum L.) roots. Imaging of reactive oxygen species and nitric oxide accumulation in vivo. Plant Cell Environ. 29, 1532-1544. doi: 10.1111/j.1365-3040.2006.01531.x

Römheld, V., and Marschner, H. (1986). Evidence for a specific uptake system for iron phytosiderophores in roots of grasses. Plant Physiol. 80, 175-180. doi: 10.1104/pp.80.1.175

Saito, K., Kurosawa, M., Tatsuguchi, K., Takagi, Y., and Murakoshi, I. (1994). Modulation of cysteine biosynthesis in chloroplasts of transgenic tobacco overexpressing cysteine synthase [O-acetylserine (thiol)-Iyase]. Plant Physiol. 106, 887-895. doi: 10.1104/pp.106.3.887

Sandalio, L. M., Rodríguez-Serrano, M., Romero-Puertas, M. C., and Luis, A. (2008). Imaging of reactive oxygen species and nitric oxide in vivo in plant tissues. Methods Enzymol. 440, 397-409. doi: 10.1016/S0076-6879(07)0 0825-7

Scandalios, J. G., Tsaftaris, A. S., Chandlee, J. M., and Skadsen, R. W. (1983). Expression of the developmentally regulated catalase (Cat) genes in maize. Dev. Genet. 4, 281-293. doi: 10.1002/dvg.1020040406

Seelig, G. F., and Meister, A. (1985). Glutathione biosynthesis; gammaglutamylcysteine synthetase from rat kidney. Methods Enzymol. 113, 379-390. doi: 10.1016/S0076-6879(85)13050-8

Singh, A. P., Dixit, G., Mishra, S., Dwivedi, S., Tiwari, M., Mallick, S., et al. (2015). Salicylic acid modulates arsenic toxicity by reducing its root to shoot translocation in rice (Oryza sativa L.). Front. Plant Sci. 6:340. doi: 10.3389/fpls.2015.00340

Singh, H. P., Batish, D. R., Kaur, G., Arora, K., and Kohli, R. K. (2008). Nitric oxide (as sodium nitroprusside) supplementation ameliorates Cd toxicity in hydroponically grown wheat roots. Environ. Exp. Bot. 63, 158-167. doi: 10.1016/j.envexpbot.2007.12.005

Singh, H. P., Kaur, S., Batish, D. R., Sharma, V. P., Sharma, N., and Kohli, R. K. (2009). Nitric oxide alleviates arsenic toxicity by reducing oxidative damage in the roots of Oryza sativa (rice). Nitric Oxide 20, 289-297. doi: 10.1016/j.niox.2009.02.004

Smith, I. K., Vierheller, T. L., and Thorne, C. A. (1988). Assay of glutathione reductase in crude tissue homogenates using 5, 5'-dithiobis (2-nitrobenzoic acid). Anal. Biochem. 175, 408-413. doi: 10.1016/0003-2697(88)90564-7

Song, W. Y., Park, J., Mendoza-Cózatl, D. G., Suter-Grotemeyer, M., Shim, D., Hörtensteiner, S., et al. (2010). Arsenic tolerance in Arabidopsis is mediated by two ABCC-type phytochelatin transporters. Proc. Natl. Acad. Sci. U.S.A. 107, 21187-21192. doi: 10.1073/pnas.1013964107

Srivastava, S., and Dubey, R. S. (2012). Nitric oxide alleviates manganese toxicity by preventing oxidative stress in excised rice leaves. Acta Physiol. Plant. 34, 819-825. doi: 10.1007/s11738-011-0863-0

Srivastava, S., Srivastava, A. K., Sablok, G., Deshpande, T. U., and Suprasanna, P. (2015). Transcriptomics profiling of Indian mustard (Brassica juncea) under arsenate stress identifies key candidate genes and regulatory pathways. Front. Plant Sci. 6:646. doi: 10.3389/fpls.2015.00646

Sun, C., Lu, L., Liu, L., Liu, W., Yu, Y., Liu, X., et al. (2014). Nitrate reductase-mediated early nitric oxide burst alleviates oxidative damage induced by aluminum through enhancement of antioxidant defenses in roots of wheat (Triticum aestivum). New Phytol. 201, 1240-1250. doi: 10.1111/nph. 12597

Takahashi, M., and Morikawa, H. (2014). Nitrogen dioxide is a positive regulator of plant growth. Plant Signal. Behav. 9, 1304-1315. doi: 10.4161/psb. 28033

Tian, X., and Lei, Y. (2006). Nitric oxide treatment alleviates drought stress in wheat seedlings. Biol. Plant. 50, 775-778. doi: 10.1007/s10535-006-0129-7

Tripathi, R. D., Srivastava, S., Mishra, S., Singh, N., Tuli, R., Gupta, D. K., et al. (2007). Arsenic hazards: strategies for tolerance and remediation by plants. Trends Biotechnol. 25, 158-165. doi: 10.1016/j.tibtech.2007.02.003

Velikova, V., Yordanov, I., and Edreva, A. (2000). Oxidative stress and some antioxidant systems in acid rain-treated bean plants: protective role of exogenous polyamines. Plant Sci. 151, 59-66. doi: 10.1016/S01689452(99)00197-1

Xiang, C., and Oliver, D. J. (1998). Glutathione metabolic genes coordinately respond to heavy metals and jasmonic acid in Arabidopsis. Plant Cell 10, 1539-1550. doi: 10.1105/tpc.10.9.1539

Xu, X. Y., McGrath, S. P., and Zhao, F. J. (2007). Rapid reduction of arsenate in the medium mediated by plant roots. New Phytol. 176, 590-599. doi: 10.1111/j.1469-8137.2007.02195.x

Yokosho, K., Yamaji, N., Ueno, D., Mitani, N., and Ma, J. F. (2009). OsFRDL1 is a citrate transporter required for efficient translocation of iron in rice. Plant Physiol. 149, 297-305. doi: 10.1104/pp.108.128132

Yu, C. C., Hung, K. T., and Kao, C. H. (2005). Nitric oxide reduces Cu toxicity and $\mathrm{Cu}$-induced $\mathrm{NH} 4+$ accumulation in rice leaves. J. Plant Physiol. 162, 1319-1330. doi: 10.1016/j.jplph.2005.02.003

Conflict of Interest Statement: The authors declare that the research was conducted in the absence of any commercial or financial relationships that could be construed as a potential conflict of interest.

Copyright (C) 2016 Singh, Dixit, Kumar, Mishra, Singh, Dwivedi, Trivedi, Chakrabarty, Mallick, Pandey, Dhankher and Tripathi. This is an open-access article distributed under the terms of the Creative Commons Attribution License (CC BY). The use, distribution or reproduction in other forums is permitted, provided the original author(s) or licensor are credited and that the original publication in this journal is cited, in accordance with accepted academic practice. No use, distribution or reproduction is permitted which does not comply with these terms. 